\title{
Evaluation of Non-oil Export Stimulation Facility and Non-oil Export Performance: Nigerian Paradigm
}

\author{
GBARATO Ledum Moses ${ }^{1 *}$, COOKEY Sunny Chekiri Monday ${ }^{2}$, VISAN Callistus Giobari ${ }^{3}$ \\ ${ }^{1}$ Department of Finance \& Banking, University of Port Harcourt, Nigeria \\ ${ }^{2,3}$ Ph.D Scholars, Department of Banking \& Finance, Rivers State University, P.M.B. 5080, Port Harcourt, Nigeria
}

DOI: $10.36348 /$ sjef.2020.v04i08.006

*Corresponding author: GBARATO Ledum Moses
| Received: 09.08.2020 | Accepted: 17.08.2020 | Published: 19.08.2020

Email: ledum4success@gmail.com

\section{Abstract}

The focal interest in this study has been to critically evaluate the trend of non-oil-export-stimulation facility (NESF) as well as non-export performance in Nigeria. The NESF is a 10-year tenure CBN debenture investment that worth N500 billion naira as credit to non-oil export sector with commencement from 2017. Although, NESF experienced a halt in the process due to forensic auditing of perceived corruption in Nigerian Export and Import Bank (NEXIM) operations which has crippled earlier similar programmes, a cursory look at NESF through percentage growth and graphical trend of nonoil export extracted from CBN Statistical bulletin 2019 reveals remarkable increase in the trend of non-oil export activities from 2017 to 2019 being the incubating as well as implementation period. While negative growth rates of $15.5 \%, 30.8 \%$ and $0.6 \%$ were recorded in 2014, 2015 and 2016 respectively, in 2017, 2018 and 2019, there was positive and remarkable growth rate in non-oil export sector by $63.7 \%, 32.6 \%$ and $124.9 \%$ respectively. Also, from ARDL result, non-oil export positively influences RGDP. This suggests that with prudent administration of the NESF, there abound great hope in the economic growth of Nigeria. Therefore, the study recommended that concerned beneficiaries of NESF should maximize accrued advantages of this opportunity especially its favourable repayment-period-spread and rates, with a two-year moratorium. Also, the rebranded NEXIM should take it as a foremost duty to scrutinized, monitor and reprimand where necessary for the attainment of NESF nominated objectives. Finally, improvement in infrastructure needed for export promotion should be strengthened.

Keywords: CBN, Credit Facility, Non-oil Export, Nigerian Growth.

Copyright @ 2020: This is an open-access article distributed under the terms of the Creative Commons Attribution license which permits unrestricted use, distribution, and reproduction in any medium for non-commercial use (NonCommercial, or CC-BY-NC) provided the original author and source are credited.

\section{INTRODUCTION}

Exports have been identified as a sine qua non for the attainment of basic necessities needed for expansion of productive capacity of nations [1]. Promotion of export activities helps to beef up revenue sources, create job opportunities; fix balance of payment disequilibrium and wheel in sustainable economic growth. And economic growth is the heart beat priority of most emerging countries, which Nigeria is one [2].

Treading on this path has been the experience in Nigeria before the exploration and commercialization of crude oil in 1970, when produce from our arable land such as the production of palm oil, cocoa, groundnut, beans, melon, corns, rice, among others were been exported to other countries [3]. In retracing our steps, NGOs, government and its agencies have made several effort to regain back our national pride. Programmes such as: structural adjustment programme (SAP) in 1986, Commercial agricultural credit scheme of N200b in 2003; Real Sector Support Facility of N300b in 2010; Anchor Borrowers' Programme in 2013 (Funded from MSMEDF), Textile Sector Intervention Facility of N50b in 2015, then Non-oil Export Stimulation Facility of N500b in 2016, and Accelerated Agricultural Development Scheme in 2017 [4] have been initiated all in the effort of promoting export activities and ensuring sustainable economic growth.

Nigeria is an enviable country blessed with natural endowment of various kinds of economic resources capable of catapulting her amongst the developed economies of the world [5, 3]. Regrettably, the reverse is the case, due to greed, misappropriation of public fund; poor design and implementation of education curriculum, failure in policy implementation, and lack of modern explorative and transformative 
technology needed to judiciously harness these resources.

More so, Nigeria's plague of 'monoeconomy' syndrome where there is overdependence on oil activities as the major source of revenue to Nigeria is an opportunity of diminishing return. The monomania situation of oil instead of becoming a great blessing is like a curse that has greatly limited our position of growth. This condition has not only skewed empowerment to only those that have connections to oil and oil related dealers but also created mentality of 'if not job in Oil Company, oil related company or being a politician, then a mean job' at the detriment of non-oil export related sectors. Also, its associated risk of price fluctuation, resulting to volatile oil export income in the country is a thing of great worry [6].

Moreover, capital remains a key constraint to the outlook and operations of the Nigerian Export and Import Bank (NEXIM). Adefeko [7] argues that how can non-oil export increase in the midst of incessant financial assistance decline over the years. For instance, $\mathrm{CBN}$ consolidated balance sheet release in first quarter of 2016 was N66.5bn and by the fourth quarter of 2016, the value declined to N2.6bn which is greatly in contrast with China Export and Import Bank (EXIM) with \$500bn in total assets as at 2016 [7].

Despite all the government efforts in the past to re-strengthen the non-oil export sector, it appears little or no positive impact has been recorded. It is on this premise and sparse literature on the extent of the implementation of export stimulation strategy that stimulates the curiosity for a critical evaluation of the non-oil export stimulation facility as well as export performance, as one of the recent government economic programme with a huge funding capacity. Therefore, objectively, this study seeks to:

i. Ascertain the implementation level of the nonexport stimulation strategy in Nigeria.

ii. Determine the influence of non- oil export on real gross domestic product in Nigerian.

iii. Evaluate the role of gross fixed capital formation in real gross domestic product in Nigerian.

iv. Examine the prediction of exchange rate on real gross domestic product in Nigerian.

It is believed that outcome of this study can aid relevant authorities to beef up the process haven realized plausible areas of redress.

\section{Concept of Non-oil Export}

Non-oil exports are viewed as commodities not including crude oil (petroleum products), sold in the international market as a means of raising national income [8]. Akeem [9] posits that non-oil exports sector is organized into four major categories; manufactured exports, agricultural exports, solid mineral exports and services exports [9]. Agricultural crops, manufacturing goods, solid minerals, and entertainment and tourism services are some of the items of non-oil export products [10].

\section{Concept of Non-oil Export Stimulation Facility}

The Non-Oil Export Stimulation Facility (NESF) was established by the Central Bank of Nigeria (CBN) in 2016 to diversify the economy away from oil and to expedite the growth and development of the nonoil export sector. The recent fall in global prices of crude oil triggered a sharp decline in the country's revenue and foreign exchange earnings [11].

The facility is essentially designed to redress the declining export credit and reposition the sector to increase its contribution to revenue generation and economic development. It will improve export financing, increase access of exporters to low interest credit and offer additional opportunities for them to upscale and expand their businesses in addition to improving their competiveness. It was established that at its implementation, investment of a N500 billion debenture by the CBN to be issued by Nigerian ExportImport Bank (NEXIM) in line with section 31 of CBN Act [11].

\section{A) Objectives of Non-oil Export Stimulation Facility}

As stated in the CBN report [11], majorly, the Non-Oil Export Stimulation Facility was to attain the following objectives:

a) Improve access of exporters to concessionary finance to expand and diversify the non-oil export baskets;

b) Attract new investments and encourage reinvestments in value-added non-oil exports production and non-traditional exports;

c) Shore up non-oil export sector productivity and create more jobs;

d) Support export oriented companies to upscale and expand their export operations as well as capabilities;

e) Diversify and increase the level of contribution of non-oil exports revenue towards sustainable economic development; and

f) Broaden the scope of export financing instruments.

Also, clear statement of eligibility criteria for borrowers as well as beneficiaries was given. That, only export-oriented enterprises shall be eligible under the ESF, such shall include be:

a) A company duly incorporated in Nigeria under Companies and Allied Matters Act (CAMA).

b) An Enterprise with verifiable export off-take contract(s).

c) An Enterprise with satisfactory credit reports from at least two Credit Bureaus in line with the provisions of $\mathrm{CBN}$ Circular BSD/DIR/GEN/CIR/04/014 dated April 30, 2010 . 
d) Eligible Bank Asset (EBA) purchased by Asset Management Corporation of Nigeria (AMCON), that may by special approval of the CBN Management, be allowed to participate with respect to acquired projects of national economic importance, proven potentials to export, good prospects to attract new investors and ability to repay EBA obligations to AMCON [11].

e) Deposit Money Banks and Development Finance Institutions with exception to NEXIM as financial institutions are eligible to participate under the policy.

In addition, all applications shall be in compliance with CBN circulars BSD/DIR/GEN/LAB/07/015 and BSD/DIR/GENLAB/07/034 on "Prohibition of Loan Defaulters from Further Access to Credit Facilities in the Nigerian banking System" and "Guidelines for Processing Requests from DMBs to Extend New/Additional Credit Facilities to Loan Defaulters and AMCON Obligors" dated June 30, 2014 and October 10,2014 respectively.

\section{B) Features of Non-oil Export Stimulation Facility}

\section{i. Lending Limit}

a) The Facility shall not exceed $70 \%$ of the total cost of the project or transaction subject to a maximum of five billion Naira

\section{ii. Tenor}

The ESF shall have a tenor of up to 10 years and shall not exceed the 28th of December, 2025.

a) Stocking facility shall be for a maximum tenor of one year with the option of roll-over not exceeding twice. However, this shall attract an additional fee of $0.25 \%$ per annum of the loan amount and is subject to approval of CBN.

b) Working capital facility shall be for a maximum tenor of one year with the provision of roll-over not exceeding twice. However, this shall attract an additional fee of $0.25 \%$ per annum of the loan amount and is subject to approval of CBN.

\section{iii. Repayment}

Repayments of principal components of loans and interest shall be quarterly.

\section{iv. Moratorium}

a) Moratorium shall be project specific and shall not exceed two (2) years.

b) In case of construction, additional moratorium of up to twelve [12] months may be allowed. However, this shall attract an additional fee of $0.25 \%$ per annum of the loan amount.

\section{v. Interest Rates}

The Facility shall be availed at an "all-in" Interest rate, based on risk based pricing model as per CBN Circular
BSD/DIR/GEN/CIR/04/015 of April 30, 2010 as follows:

a) Facilities with a tenor of up to three (3) years, would be granted at a maximum all-in interest rate of seven and half percent $(7.5 \%)$ per annum

b) Facilities with tenor of over three (3) years, would be granted at a maximum all-in interest rate of nine percent $(9 \%)$ per annum

\section{Structure of Interest Computation under the NESF shall be as follows \\ a) Participating Financial Institutions - maximum spread of $6 \%$ per annum \\ b) Managing Agent (NEXIM) - $1 \%$ per annum \\ c) Central Bank of Nigeria $(\mathrm{CBN})-2 \%$ per annum}

\section{vi. Approval Process}

All appraised applications by NEXIM shall be forwarded to the Central Bank of Nigeria for consideration and approval.

\section{vii. Collateral Requirement}

PFIs shall submit Irrevocable Standing Payment Order (ISPO) in respect of all projects approved under the scheme.

\section{viii. Participation Agreement}

A participation agreement shall be signed between NEXIM and each PFI

\section{ix. Monitoring and Evaluation}

Monitoring and Evaluation of projects funded under the facility shall include:

a) On-site and Off-site verification and routine monitoring of projects under the facility by CBN, NEXIM and PFIs during the loan period

b) Provision to all concerned parties with the report of monitoring exercise

c) Periodic evaluation of the activities of all participating Financial Institutions and beneficiary projects to ensure adherence to the objectives of the facility

\section{x. Penalty for Defaults}

a) In the event of default in loan repayment of principal and/or interest by the borrower, the PFIs shall have the right to charge its prevailing interest rate on the amount in default.

b) In the event of diversion of funds by the PFI, the amount diverted shall be recovered by NEXIM and the PFI shall be barred from further participation under the facility and access to official foreign exchange window.

c) Failure of PFI to disburse funds within 3 working days of receipt to the borrower shall attract a penal charge of MPR +300 basis 
points for the period that funds were not disbursed, and

d) Non-rendition of returns or the rendition of false returns shall attract the penalty stipulated by BOFIA Act Section 60 .

\section{Appraisal of the Non-oil Export Strategy Facility (NESF)}

The non-oil exporting strategy facility (NESF) indeed is a welcome development considering the status quo that gave birth to this economic policy where in 2015; Nigeria recorded the lowest exports in three years. The value of exports, According to the National Bureau of Statistics [12], declined from N16.304bn in 2014 to N9.729bn in the fourth quarter of 2015, representing a decline of 40.3 percent. Consequently, the Nigerian Export Promotion Council (NEPC) stressed the need to scale up non-oil exports so that the country can compete favourably in the global market [13].

Kick starting this program in 2018, with a tenure of 10 years facility expiring $31^{\text {st }}$ December, 2027, raised the hope of many non-oil foreign trade dealers, most especially as Godwin Emefiele, the CBN governor affirmed the inclusion of eligible transactions to cover export of goods wholly or partly processed or manufactured in Nigeria, and export of commodities and services which are permissible and excluded under existing export prohibition list, import of plant and machinery, spare parts and packaging materials required for export oriented production that cannot be produced locally, as well as export value chain support services such as transportation, warehousing and quality assurance infrastructure, modernization and technology upgrade of non-oil export industries [13, 14]. These will be a boost to big time local manufacturers looking for incentives in the export and import market.

Consequently, some moribund manufacturing companies have been earmarked to be revived by this giant economic strategy. Tokele [15] asserts that Dr. Frank Jacobs commended the CBN for its motivation to revive the moribund manufacturing companies in the country. According to him,

To revive the moribund manufacturing sector is a welcome idea by the CBN governor since those were the things we have been expecting. There are several strategic companies that are moribund across the country.

Still in the spirit of resuscitating the export sector for sustainable economic growth, the Central Bank of Nigeria unveiled the Export Facilitation Initiatives (EFI) on the $14^{\text {th }}$ of June, 2019 all as a follow-up strategy to the full implementation as well as realization of expected remarkable growth in the nonoil export sector [16]. Under the initiative, the focal commodities for value chain development include: cocoa, cashew, palm oil, Shea and sesame seed.

However, an uproar arose in 2019 as a result of perceived bottleneck associated in the disbursement of ESF which led to $\mathrm{CBN}$ revamped the facility, on allegations of high-level fraud in the disbursement of loans by the former Nigerian Export-Import Bank (NEXIM) management team [17]. Sequel to this situation, a forensic audit commissioned by the new board of directors, led by Dr. Okwu Joseph Nnanna, a deputy governor, who represents the interest of the $\mathrm{CBN}$, had exposed different levels of procedural abuse at NEXIM [17]. This was a bold step taken by the CBN governor to fight against 'killers' of economic growth strategies in Nigeria.

\section{Theoretical Underpinning}

Adam Smith and David Ricardo, the classical economists, in their publications in 1776 and 1817 respectively, contended that international trade is a major inducement in economic growth improvement [18].

\section{(i) The Theory of Absolute Advantage}

The theory of absolute advantage advocated by Adam Smith in 1776 is a transnational trade theory that expounds the essence of trade among countries. The theory posits that a country should major in export of commodities of which it has greater productive advantages over other countries. That is goods for which it can produce more output per unit of input than others can. This calls for importation of goods of which a country is less productive than other countries. That is goods on which it has an absolute disadvantage [19].

Although, the theory sees specialization that leads to mass production, cost reduction, increase in world output, as well as simultaneous gain by participating countries as associated benefits if involved, however, there is a worry of the fate of other countries, in the case where a country is proficient to produce many commodities in comparison with others. This unanswered worry prompted Ricardo's theory of Comparative Advantage [19].

\section{(ii) Theory of Comparative Advantage}

Ricardo's theory of comparative advantage posits that even if a nation has an absolute cost disadvantage in the production of both goods, there still exists a basis for mutually beneficial trade. The less efficient nation should specialize in the production and exportation of the good in which it is relatively less inefficient (where its absolute disadvantage is least) while the more efficient nation should specialize in the production and exportation of the good in which it is relatively more efficient. That is where its absolute advantage is greatest [20]. 
Applying these theories in Nigerian economy, the country is a fortunate one endowed with diverse natural resources efficient for advantageous mass production especially in agricultural products (such as palm kernel, rubber; cocoa, cotton; coffee, beniseed; groundnut, among others), mineral exploration of graphite, columbite; uranium, iron ore; coal, tin, etc. Thus, these theories of trade describe how Nigeria could diversify its exports away from oil [20].

\section{Synopsis of Related Studies}

Table-1: Showing empirical studies on non-export and economic growth nexus

\begin{tabular}{|c|c|c|c|c|}
\hline $\begin{array}{l}\mathrm{S} / \\
\mathrm{N}\end{array}$ & Author (s) & Study & $\begin{array}{c}\text { Employed } \\
\text { Techniques }\end{array}$ & Findings \\
\hline 1 & $\begin{array}{l}\text { Aladejare \& Saidi } \\
\text { [21] }\end{array}$ & $\begin{array}{l}\text { The impact of aggregate non-oil } \\
\text { sector and its determinant on } \\
\text { economic growth in Nigeria } \\
(1970-2012) \text {. }\end{array}$ & Bound Test & $\begin{array}{l}\text { Presence of positive and significant long and } \\
\text { short run relationship }\end{array}$ \\
\hline 2 & Raheem [22] & $\begin{array}{l}\text { The role of oil and non-oil exports } \\
\text { on the Nigerian economy (1981 - } \\
\text { 2015) }\end{array}$ & $\begin{array}{l}\text { i.Co-integration } \\
\text { test } \\
\text { ii. ECM } \\
\text { iii.Granger } \\
\text { Causality test }\end{array}$ & $\begin{array}{l}\text { i) GDP, Oil and non-oil exports were co- } \\
\text { integrated. } \\
\text { ii) Negative relationship between oil export } \\
\text { and GDP. } \\
\text { iii)Positive relationship between non-oil } \\
\text { export and GDP } \\
\text { iv) Bidirectional relationship between oil } \\
\text { export and GDP } \\
\text { v) Non-oil export promotes GDP }\end{array}$ \\
\hline 3 & Vincent [23] & $\begin{array}{l}\text { An analysis of the impact of non- } \\
\text { oil export and economic growth in } \\
\text { Nigeria (1980-2016) }\end{array}$ & $\begin{array}{l}\text { Engel Granger } \\
\text { Model }\end{array}$ & $\begin{array}{l}\text { Strong evidence of co-integration relationship } \\
\text { of non-oil export in influencing GDP }\end{array}$ \\
\hline 4 & Kromtit et al. [8] & $\begin{array}{l}\text { the contribution of non-oil export } \\
\text { to the growth of the Nigerian } \\
\text { economy (1985-2015) }\end{array}$ & ARDL & $\begin{array}{l}\text { Presence of positive and significant } \\
\text { relationship between non-oil exports and GDP }\end{array}$ \\
\hline 5 & $\begin{array}{l}\text { Omoruyi \& } \\
\text { Uwbamwen [24] }\end{array}$ & $\begin{array}{l}\text { Export performance and economic } \\
\text { growth nexus in Nigeria (1981- } \\
\text { 2010) }\end{array}$ & $\begin{array}{l}\text { i. ECM } \\
\text { ii.Granger } \\
\text { Causality test }\end{array}$ & $\begin{array}{l}\text { i)Positive relationship between non-oil export } \\
\text { and GDP } \\
\text { ii) Non-oil export promotes GDP }\end{array}$ \\
\hline 6 & Okeke \& Eze [25] & $\begin{array}{l}\text { The impact of Oil and Non-Oil } \\
\text { Products on Nigeria Gross } \\
\text { Domestic Product (1981-2016) }\end{array}$ & OLS & $\begin{array}{l}\text { i)Oil export exerts positive but marginal } \\
\text { influence on GDP } \\
\text { ii) Non-oil export exerts positive and } \\
\text { significant influence on GDP }\end{array}$ \\
\hline 7 & Musa et al. [6] & $\begin{array}{l}\text { The impact of non-oil export on } \\
\text { economic growth in Nigeria } \\
\text { (1981-2018) }\end{array}$ & ARDL & $\begin{array}{l}\text { Positive and significant relationship between } \\
\text { non-oil export and GDP }\end{array}$ \\
\hline
\end{tabular}

Source: Authors' Compilation, 2020

A catalogue of extant related literature all indicate positive and significant relationship between non-oil export and economic growth in Nigeria as observed from 2014 to 2020 related studies. However, most studies neglected key non-oil export determinant variables such as gross fixed capital formation (GFCF) and exchange rate, with exception of Omoruyi and Uwbamwen (2018) whose study period ended 2010. Also, there is no trace of literature on the evaluation of non-oil export stimulation facility initiated by the central bank of Nigeria 2016 in relation to Nigerian non-oil export. This creates a gap that needed to be justified, thus, necessitating this study.

\section{METHODOLOGY}

Consequently, times series data on the variables for the period (1981-2019) are used for this study which was sourced from central bank of Nigeria Statistical bulletin [25]. The graph is employed to evaluate the export stimulation facility on export trend. Thereafter, export performance and economic growth nexus examined, adapting from Omoruyi and Uwbamwen [24] model. The model is this study is specified as:

$\mathrm{RGDP}=\mathrm{f}(\mathrm{NOE}, \mathrm{GFCF}, \mathrm{EXR}) \quad$ (i)

Linearizing equation (i) with natural logarithm thus becomes:

$\operatorname{LnRGDP}_{t}=\beta_{0}+\beta_{1} \operatorname{Ln} \mathrm{NOE}_{\mathrm{t}}+\beta_{2} \mathrm{Ln} \mathrm{GFCF}_{\mathrm{t}}+\beta_{3} \mathrm{EXR}_{\mathrm{t}}+\mu_{\mathrm{t}}$ (ii)

Where; $\beta o=$ Constant; RGDP $=$ Real Gross Domestic Product; NOE = Non-oil Export; GFCF = Gross Fixed Capital formation; $\mathrm{EXR}=$ Exchange rate; $\mathrm{t}=$ at time $\mathrm{t}$; $\mu=$ Error (Disturbance) term; $\beta_{1}, \beta_{2}, \beta_{3}=$ coefficients. The a priori expectations are given as $\beta_{1}, \beta_{2}, \beta_{3}>0$.

\section{Data and Empirical Methods}

A statistical examination of the non-oil export within the short period of non-oil export stimulation facility (NESF) implementation (2017 - 2019). 


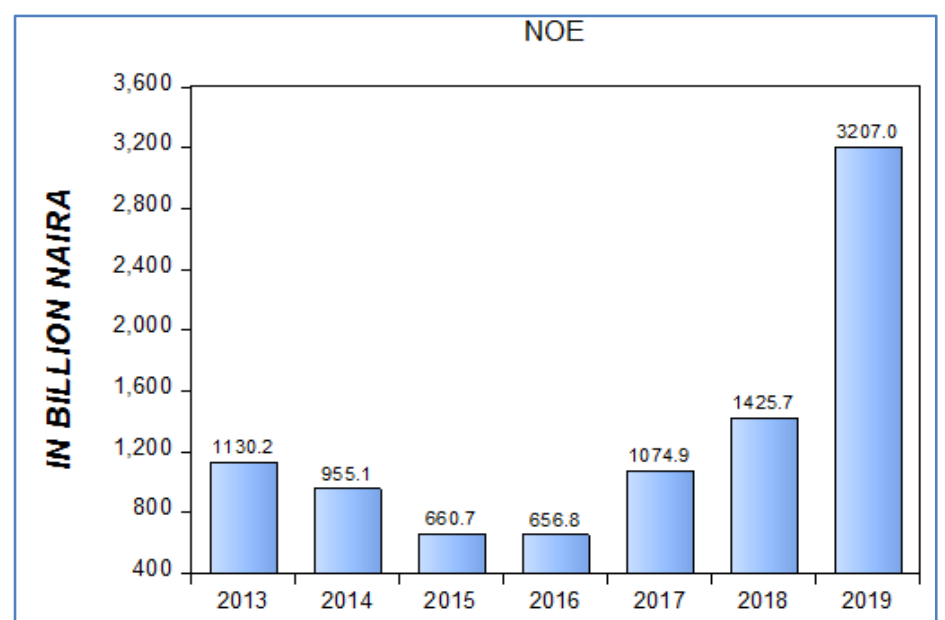

Fig-1: Showing Graphical trend of values of Non-oil Export in Nigeria in Billion Naira form 2013 to 2019 Source: Eview Output

The figure above reveals that remarkable increase in the trend of non-oil export activities from 2013 to 2019, although, 2017 was the incubating as well as implementation period of the non-oil export strategy facility. While negative growth rates of $15.5 \%$, $30.8 \%$ and $0.6 \%$ were recorded in 2014, 2015 and 2016 respectively, however, in 2017, 2018 and 2019, there was positive and remarkable percentage growth rate in non-oil export sector by $63.7 \%, 32.6 \%$ and $124.9 \%$ respectively. This is an indication of rapid influx of economic activities channeled towards production and promotion of export goods such as mineral products, vegetables; rubber, wood; textiles, articles of stone, plastic, cement and ceramics; articles of base metals, articles of pearls, precious and semi-precious stones, as well as other miscellaneous manufacturing articles, consequent of the stimulation export facility. As an alternative to the oil export, when there is expansion in the non-oil export sector, it does not only creates more job opportunities but also helps in fixing balance of payment problem, improves the standard of living as well as increasing savings and investments, thereby, promoting the economic growth and development of the country.

\section{Stationarity Test}

Table-2: ADF Stationary (Unit Root) Test Result

\begin{tabular}{|c|c|c|c|c|}
\hline Variable & ADF stat & Critical Value at 5\% & Order of Integration & P-value \\
\hline LNRGDP & -7.967213 & -3.540328 & $1(1)$ & 0.0000 \\
\hline LNNOE & -6.964902 & -3.536601 & $1(1)$ & 0.0000 \\
\hline LNGFCF & -4.218530 & -3.533083 & $1(0)$ & 0.0100 \\
\hline EXR & -4.509498 & -3.536601 & $1(1)$ & 0.0049 \\
\hline
\end{tabular}

Source: E-view 10 Output on 1981 to 2019 CBN Bulletin Data.

The ADF unit root test result as shown in table 2 indicates a fractional integration, where LNRGDP, LNNOE and EXR are stationary at difference 1(1), whereas, LNGFCF is stationary at level. Therefore, the use of ARDL method for data analysis in this study has been justified.

Table-3: Heteroskedasticity Test

\begin{tabular}{|c|c|c|c|}
\hline \multicolumn{3}{|c|}{ Heteroskedasticity test: Harvey } & P-value \\
\hline F-statistic & 0.999259 & Prob. $F(21,13)$ & 0.4658 \\
\hline Obs*R-squared & 9.259659 & Prob. Chi-Square(21) & 0.4137 \\
\hline Scaled explained SS & 8.979466 & Prob. Chi-Square(21) & 0.4392 \\
\hline
\end{tabular}

Source: E-view 10 Output on 1981 to 2019 CBN Bulletin Data.

The residual and normality in the model was checked using the result of Harvey heteroskedasticity test displayed in Table 3, the estimated sample shows a probability level of 0.4658 which is greater than the 0.05 significance level, also, the observed $\mathrm{R}^{2}$ of 9.259659 of which its P-value (0.4137) greater than
0.05 , this leads to the acceptance of the null hypothesis which shows that there is no existence of heteroskedasticity problem in the employed study model showing that variables are influenced from the error term more than internally and it also validates the classical linear regression model assumption (CLRMA). 
Table-4: Presentation of Bound Test Co-Integration Output

\begin{tabular}{|c|c|c|}
\hline \multicolumn{3}{|c|}{ ARDL bounds test } \\
\hline \multicolumn{3}{|c|}{ Date: $08 / 05 / 20$ Time: $18: 49$} \\
\hline \multicolumn{3}{|c|}{ Sample: 19812019} \\
\hline \multicolumn{3}{|c|}{ Included observations: 35} \\
\hline \multicolumn{3}{|c|}{ Null hypothesis: No long-run relationships exist } \\
\hline Test statistic & Value & $\mathbf{k}$ \\
\hline F-statistic & 11.53313 & 3 \\
\hline \multicolumn{3}{|c|}{ Critical Value Bounds } \\
\hline Significance & I(0) Bound & 1(1) Bound \\
\hline $10 \%$ & 2.37 & 3.2 \\
\hline $5 \%$ & 2.79 & 3.67 \\
\hline $2.5 \%$ & 3.15 & 4.08 \\
\hline $1 \%$ & 3.65 & 4.66 \\
\hline
\end{tabular}

Source: E-view 10 Output on 1981 to 2019 CBN Bulletin Data.

As revealed in Table 4, since the F-statistics of 11.53313 is greater than the upper and lower bound statistics at all levels (1\%-10\%), therefore, the null hypothesis will be rejected, implying that there is a long run association between the variables under investigation.

\section{Autoregressive Distributive Lag (ARDL)}

The lag order selection for our ARDL model was based on the Akaike information criterion (AIC). From the optimum lag length selection exercise, the minimum values of the AIC which is -4.04 , and the model that gives this minimum value is $\operatorname{ARDL}(1,2,0$, 3 ). This implies that a model that includes one lag of the dependent variable (LNRGDP), two lag of LNNOE, zero lag of LNGFCF and three lag of EXR, is the best description of our time series data.

Table-5: Showing Estimation Relationship between Non-oil Export Determinants and RGDP, using the Autoregressive Distributed Lag (ARDL) Model

\begin{tabular}{|c|c|c|c|c|}
\hline \multicolumn{4}{|c|}{ Dependent Variable: LNRGDP(-1) } & \\
\hline \multicolumn{5}{|c|}{ Method: ARDL } \\
\hline \multicolumn{5}{|c|}{ Date: $08 / 06 / 20$ Time: 08:18 } \\
\hline \multicolumn{5}{|c|}{ Sample (adjusted): 19852019} \\
\hline \multicolumn{5}{|c|}{ Included observations: 35 after adjustments } \\
\hline \multicolumn{5}{|c|}{ Maximum dependent lags: 4 (Automatic selection) } \\
\hline \multicolumn{5}{|c|}{ Model selection method: Akaike info criterion (AIC) } \\
\hline \multicolumn{5}{|c|}{ Dynamic regressors (4 lags, automatic): LNNOE(-1) LNGFCF EXR(-1) } \\
\hline \multicolumn{5}{|l|}{ Fixed regressors: $\mathrm{C}$} \\
\hline \multicolumn{5}{|c|}{ Number of models evalulated: 500} \\
\hline \multicolumn{5}{|c|}{ Selected Model: ARDL $(1,2,0,3)$} \\
\hline \multicolumn{5}{|c|}{ Note: final equation sample is larger than selection sample } \\
\hline & & & & \\
\hline Variable & Coefficient & Std. Error & $\mathrm{t}$-Statistic & Prob.* \\
\hline & & & & \\
\hline LNRGDP(-1) & 0.818517 & 0.059068 & 13.85710 & 0.0000 \\
\hline LNNOE(-2) & 0.016483 & 0.013690 & 1.204006 & 0.2399 \\
\hline LNGFCF & -0.028991 & 0.017988 & -1.611702 & 0.1196 \\
\hline $\operatorname{EXR}(-3)$ & 0.000888 & 0.000428 & 2.075232 & 0.0484 \\
\hline $\mathrm{C}$ & 1.877493 & 0.551405 & 3.404924 & 0.0022 \\
\hline R-squared & 0.997930 & Mean de & endent var & 10.32674 \\
\hline Adjusted R-squared & 0.997185 & S.D. dep & ndent var & 0.546806 \\
\hline S.E. of regression & 0.029013 & Akaike i & fo criterion & -4.007215 \\
\hline Sum squared resid & 0.021043 & Schwarz & riterion & -3.562829 \\
\hline Log likelihood & 80.12626 & Hannan- & uinn criter. & -3.853813 \\
\hline F-statistic & 1339.151 & Durbin- & atson stat & 1.665265 \\
\hline Prob(F-statistic) & 0.000000 & & & \\
\hline & & & & \\
\hline & & & & \\
\hline
\end{tabular}

Source: E-view 10 Output on 1981 to 2019 CBN Bulletin Data 
The results displayed in table 5, indicates that the model is statistically viable, as DW stat of 1.665265 falls within acceptable range of no serial correlation problem. Also, F-stat of 1339.151 with probability value of 0.000000 shows fitness of the estimation model. The $\mathrm{R}^{2}$ of 0.997930 shows that Non-oil export determinants account for about $99.8 \%$ of the changes that occurs in real gross domestic product (RGDP) in terms of non-oil foreign trade in Nigeria. This is to say that other factors other than non-oil export, gross fixed capital formation and exchange rate, contribute to real GDP about $0.2 \%$. Relatively, NOE and EXR are found to exhibit positive relationship with RGDP by their coefficients (0.016483 and 0.000888 respectively), with EXR being significant. However, GFCF assumes a negative and marginal relationship with RGDP by its coefficients and t-statistic probability of -0.028991 and 0.1196 respectively.

Negative influence of GFCF on RGDP is an indication that increase in fixed assets, such as buildings, electricity installation, computer software, among others does not favour economic activities in Nigeria. However, presence of non-oil export and exchange rate positive relationship with Real GDP suggests that export promotion on non-oil activities such as: agricultural crops, manufacturing goods, solid minerals and services as well as foreign exchange policy are favourable factors to output level of goods and services in Nigeria. This finding is in consonance with the studies of Musa et al. [6]; Okeke and Eze [25], whose findings reveal that non-oil export exert positive and efficient influence on real gross domestic product.

\section{CONCLUSION AND RECOMMENDATIONS}

This incessant accentuated positive growth in the non-oil export sector, therefore, suggests that with prudent administration of the non-oil export strategy facility; there abound great hope in the economic growth of Nigeria. Sequel to this development, non-oil exporters should therefore, take advantage of this opportunity provided by the CBN, especially since the facility comes under both short-term and medium term categories, with repayment period spread starting every 90 days for short-term borrowers, and over a ten-year period, with a two-year moratorium, inclusive of interest rate of nine percent for medium-term borrowers. The amount available to each borrower will not exceed 70 percent of the total cost of the project or transaction.

At no time has diversification of the economy become more expedient than now where oil price is more unstable in its dwindling as a result of the global covid-19 pandemic. The recent uncertainty in the international oil market has not only significantly reduced the revenue accruing to the government; it has also adversely affected development in other critical sectors. Therefore, reviving non-oil exports should begin with full speed and utmost commitment. Nigeria is endowed with non-oil exports like cocoa, rubber, palm produce, sesame seeds and solid minerals that are yet to be harnessed and exploited for exports in full capacity. Also, there should be proper management of the facility by ensuring that only the intended and qualified persons and companies, access the funds in order to achieve the targets of the economic programme.

\section{REFERENCES}

1. Onuorah, A. C. (2018). Role of non-oil exports in the economic growth of Nigeria, Journal of Emerging Trends in Economics and Management Sciences, 9(3): 132-140

2. Okubor, S. I. (2014). Promoting sustainable development in Nigeria through non-oil sector. Export Research on Humanities and Social Sciences, 4(8): 89.

3. Kemi, A. O. (2019). Nigeria's economy challenges: causes and way forward, Journal of Economics and Finance, 10(2), 78-82.

4. Abili, I. D. (2018). Development finance interventions of the Central Bank of Nigeria in agriculture, International Journal of Advanced Studies in Economics and Public Sector Management, 6(2), 19-31.

5. Aladejare, S. A. \& Saidi, A. (2014). Determinants of non-oil export and economic growth in Nigeria: An application of the bound test approach, Journal for the Advancement of Developing Economies, 3(1), 59-71.

6. Musa, H. M., Usman, U. U., Badawi, M. M. \& Farouq, K. M. (2020). Impact of non-oil export on economic growth in Nigeria, IOSR Journal of Economics and Finance, 2(1), 1-7.

7. Adefeko, A. (2017). Competitiveness, comparative advantage and role of NEXIM in export stimulation.

https://www.google.com/m?q=data+nonoil+export+stimulation+facility+from+central+ban $\mathrm{k}+\mathrm{of}+$ nigeria\&client $=$ ms-operamobile\&chanel=new\&espv $=1$

8. Kromtit, M. J., Kanadi, C., Ndangra, D. P. \& Lado, S. (2017). Contribution of non-oil exports to economic growth in Nigeria (1985-2015), International Journal of Economics and Finance, 9(4), 253-262.

9. Akeem, O. U. (2011). Non oilexport determinant and economic growth. European Journal of Business Management, 3(3), 236-257.

10. Abogan, O. P., Akinola, E. B., \& Baruwa, O. I. (2014). Non-oil export and economic growth in Nigeria (1980-2011). Journal of Research in Economics and International Finance, 3(1),1-11.

11. Central Bank of Nigeria. (2016). Non-oil export stimulation facility operating guidelines.

12. National Bureau of Statistics Report. (2015). 
13. National Business Extra, (2017). Assessing CBN non-oil export stimulation facility. https://nationalbusinessextra.com/2017/12/26/asse ssin-cbn-non-oil-export-stimulation-facility/

14. Ripples Nigeria. (2019, $7^{\text {th }}$ August). In one year, NEXIM bank approves n55bn to SMEs. https://www.ripplesnigeria.com/in-one-yearnexim-bank-approves-n55bn-to-smes/

15. Tokele, K. (2017, $19^{\text {th }}$ December). CBN, stakeholders harp on N500bn non-oil intervention fund. https://leadership.ng/2017/12/19/cbnstakesholders-harp-n50bn-non-oil-interventionfund/

16. Independent. (2019). CBN unveils new export initiative. https.//www.independent.ng/cbnunveils-new-export-initiative/

17. Ighomwenghian, K. (2019). NEXIM NPL ratio hits $91 \%$, CBN delays N500bn fund. https://investdata.com.ng/2019/05/nexim-nplratio-hits-91-cbn-delays-n500bn-fund/

18. Dimoso, R. I., \& Utonga, D. (2019). The nexus between export and economic growth in Tanzania International Business \& Economics Studies, 1(2), 95-107.

19. Dunn, R. M., \& Mutti, J. H. (2004). Trade and growth. International Economics, 221-241.
20. Adenugba, A. A., \& Dipo, S. O. (2013). Non-oil exports in the economic growth of Nigeria: A study of agricultural and mineral resources. Journal of Educational and Social Research, 3(2), 403.

21. Aladejare, S. A., \& Saidi, A. (2014). Determinants of non-oil export and economic growth in Nigeria: An application of the Bound Test approach, Journal for the Advancement of Developing Economies, 3(1), 60-72.

22. Raheem, A. I. (2016). Analysis of the effects of oil and non-oil export on economic growth in Nigeria, HAL-01401103v2.

23. Vincent, K. (2017). An analysis of the impact of non-oil export and economic growth in Nigeria. International of Innovative Research in Social Sciences and Strategic Management Techniques, 4(2).

24. Omoruyi, A. \& Uwbamwen, A. E. (2018). Export performance and economic growth nexus in Nigeria, ResearchGate, 329-345.

25. Okeke, C. C., \& Eze, F. C. (2019). Assessment of the impact of oil and non-oil products on Nigeria gross domestic product, Business, Management and Economics Research, 5(5), 71-76.

26. World Trade Organization. (1996). WTO Annual Report (No. 1-2). World Trade Organization. 